\title{
Reappropriation and Contestation of Post-Colonial Space in Rizal Mantovani’s Kuntilanak
}

\author{
Anton Sutandio \\ Maranatha Christian University, Indonesia
}

\begin{abstract}
This paper examines a contemporary Indonesian horror film titled Kuntilanak (2006) in the light of how the film attempts to reappropriate and contest the post-colonial space as an arena of decolonization. The post-colonial space here refers to historical buildings of the Dutch colonial legacy that can be found all over Indonesia, especially Java island. Those unfixed and fluid spaces have been re-appropriated, reconstructed, reproduced, negotiated, neglected, and destroyed during the post-colonial period as ongoing attempts to (re)define national identity. The analysis will focus on a single building that serves as the film set which possesses the characteristic of colonial architecture that represents the former Dutch colonial power. Horror genre is chosen as it is considered the most appropriate genre to talk about the past in the present and how they are related to each other, as allegorized by the old building and the monster in the film. The analysis focuses on several aspects of film studies that include mise-en-scene, the narrative, and the film stars which are later related to the politics of space and post-colonial theory. The findings show that there are intertwined modern and local values that the film offers which lead to hybrid identity.
\end{abstract}

Keywords: post-colonial space, reappropriation, contestation, decolonization

\section{Introduction}

"The past is never dead. It's not even past." (Faulker, 1951, p.73). What character Stevens said to Temple in Faulkner's Requiem for a Nun perfectly reflects Indonesia's relation to her colonial past. Indonesia can neither deny nor escape the imposed constructed identity of the colonial past that complicates the present context of national identity. "Though there was a political change, many nations got independence and no more they are colonies, but culturally and economically there appearerd many dillema and crisis, they werer still in confusion about their culture and identity" (Dizayi, 2015, p. 999). The most apparent legacies that reflect that past are the buildings, the "past in the present". They have become a crucial factor in the search for national identity. As Nas argued, the "colonial past not only plays a role in Indonesia but has also become part and parcel of presentday Dutch architecture in a broad sense" (Nas, 2006, p.13). Those unfixed and fluid spaces have been reappropriated, reconstructed, reproduced, negotiated, neglected, and destroyed during the post-colonial period as ongoing attempts to (re)define national identity which resonates Keith \& Pile's argument that "there are multiple enunciations of distinct forms of space" (Keith \& Pile, 1993, p. 6). Philpott also pointed out the need for a constant process of disrupting, dissolving, and reinscribing particular forms of identity and the spaces of cultural production to arrive at the concept of "being Indonesians" (Philpott, 2000, p. 44). The strongly imprinted memories of a colonial time as well as the symbolic power of the buildings escalated the need to understand the spaces. Kusno stated how upper-middle class Indonesians identify the buildings with modernity, power, and prosperity and, consequently, this resulted in the need to dwell in such buildings to establish their identity as different from others (Kusno, 2010, p. 135). An obvious example is the number of colonial buildings in Indonesia that have been turned into government offices. Gandhi stated that "[this] process of returning to the colonial scene [the building] discloses a relationship of reciprocal antagonism and desire between colonizer and colonized" (Gandhi, 1998, p. 4).

There are hundreds of ex-colonial buildings scattered around Indonesia, most of which are located in urban areas. In the context of film production, the most common use of those spaces are interestingly as settings in horror 
films, in which the old structures become sort of "gate" between the past and the present. This fact emphasizes that the old structures still carry the "authoritative" and feared aura, as well as underlining Babha's point on the colonial scene as "the 'other scene' of entstellung, displacement, fantasy, [and] psychic defence..." (Bhabha, 1994, p. 107). Horror films look at the structures as this distorted scene that brings the audience back to the past and makes them experience the feeling of being displaced and afraid. Some notable contemporary Indonesian horror films that highlight the colonial buildings are Nayato Fio Nuala's Hantu Ambulance (2008), Mo Brothers's Rumah Dara/Macabre (2009), Jose Poernomo's Rumah Kentang (2012), Joko Anwar's Pengabdi Setan (2017), Danur (2017), Hedy Surwayan's Rumah Belanda/Dutch House (2018), and Rizal Mantovani's Kuntilanak (2006). This paper focuses on a particular colonial building in Jakarta which became the set for Rizal Mantovani's gothic horror film Kuntilanak (Mantovani, 2006). Mantovani is one of the well-known Indonesian contemporary directors who specializes in horror genre, thus legitimizing the analysis of his film. Aitken argued that "the way spaces are used and places are portrayed in film reflects prevailing cultural norms, ethical mores, societal structures and ideologies" (Aitken, 1994, p. 5). By setting his gothic horror film in a post-colonial space, Mantovani touched on those aspects while asserting his understanding and interpretation onto the space as he entered the contesting arena of national identity search. He intended to explore the colonial past which Gandhi argued is not simply a reservoir of "raw" political experiences and practices but the scene of intense discursive and conceptual activity characterized by political identities of colonized subjects (Gandhi, 1998, p. 5). Neither the audience nor the director is a passive party, but they actively reconstruct images that they view, thus becoming involved in the identity construction the film offers. How Mantovani reappropriated and contested the postcolonial space and what contribution he offered through his interpretation will be the central analysis of this paper. The analysis focuses on several aspects of cinema that include mise-en-scene, the narrative, and the film stars which are later related to the politics of space and post-colonial theory.

The fact that a horror film is juxtaposed with weighty issues of national identity, post-colonialism and neocolonialism may seem puzzling, but it is here that one can catch a glimpse of what Adam Lowenstein called "allegorical moments," which he defines as "a shocking collision of film, spectator, and history where registers of bodily space and historical time are disrupted, confronted, and intertwined" (2). Khair provided another argument on the close relation between gothic horror with postcolonial. He stated that "the Gothic and the postcolonial are obviously linked by a common preoccupation with the Other and aspects of Otherness" (Khair, 2009, p. 3). The "Other" can have various versions in gothic horror: the devil, the women, the victim, the monster, or the colonized. In the light of his argument, gothic horror genre is a good medium to relive and reconstruct the horror of colonial time. The shocking, terrifying, and frightening images that mark a horror film make it more effective in sending its message as people are psychologically apt to react more emotionally in such conditions.

\section{Discussion}

There is no exact written data on the building but a review of the film indicated its location to be in peripheral Jakarta. It is a huge, three-story, art deco building that once may have been used as a villa. Nas provided a solid support when he mentioned that around the time of First World War, a new type of colonial villa emerged, modern in architecture, suitable as a dwelling for life in a tropical climate (Nas, 2006, p. 104). From his argument, one can safely assume that the building was built around the 1920s. As a villa, it might have been located outside Jakarta, corresponding to Nas' argument that the fast-growing demand for housing within the city caused new town extensions to more remotes areas (see figure 1). As Jakarta developed, this building was integrated within the city limits and established its present location in the periphery. 


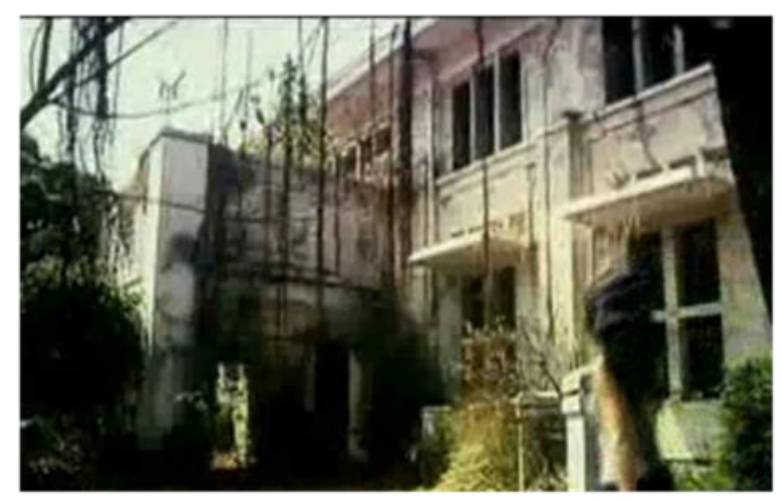

Figure 1 The exterior of the colonial building turned into a dorm in the film.

Mantovani's choice of the colonial building as the setting of his horror film was no coincidence, for he contributed to the reinforcement of a certain "fabulation" of the colonial legacies. "The word 'fabulation' evokes the 'fable' and carries forward the connotation of a folk story..." (Stenner, 2018, p. 152) An old colonial building as a mystical place is one of the myths circulating among Indonesians, and Mantovani manages to amplify. What Mantovani did to the building was to transform it into a "counter-apotropaic" site that summons rather than wards off evil.

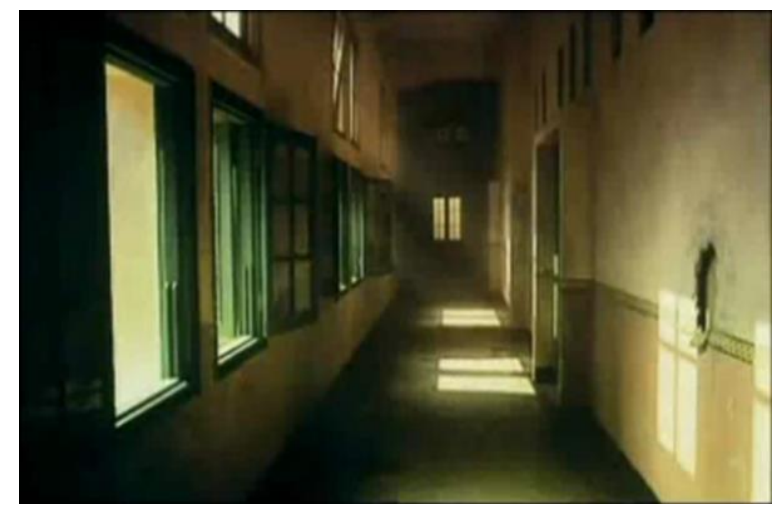

Figure 2 The dark alley inside the colonial building.

To amplify the horrifying and traumatic space of the past, Mantovani used low-key lighting, eerie music and dark haunting color. He added slow camera movements sometimes juxtaposed with fast camera movements and sudden jump-cuts to increase the intensity of horror that at the same time reflected the ambiguous feeling of the characters and the audience towards the space. As one of the characters said to the protagonist, "I've lived too long and comfortably here that I cannot leave the place even if I want to; it seems that I'm helplessly attached to the place." Her narration reflects the ambiguity between forgetting and remembering the space that affects her identity.

An old cemetery in front of the building indicated an aura of decay and forgotten past (see figure 3). 


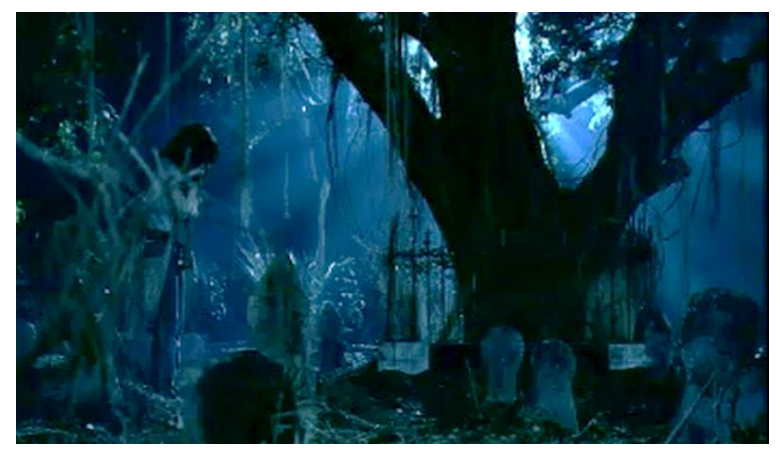

Figure 3 An old, eerie cemetery close to the building.

It seems to function as a blind separating the decayed colonial legacy and the ever-developing city. In a Javanese context, as Forshee argued that "[cemeteries] embody an authority from the past and through this embodiment offer a source of power...Individuals in Java visit tombs with their special intentions, often at times of personal crisis, in order to place themselves in relationship to a personage of the past" (Forshee, 2006, p. 119). It is clear from her argument that a cemetery is "a gate" between a human's world and the supernatural world. The cemetery as signifier of the past and the dead is turned into a frightening and creepy space that amplifies its association with the colonial building, while at the same time their juxtaposition suggests the lingering power of the colonial past. Mantovani attempted to evoke a nature of memory that Deleuze called "profound paradox of memory" when the past is "contemporaneous" with the present that it has been (Deleuze, 1988, p. 58). Davies also argued that a cemetery may become a site that activates memories when people visit and "talk to the dead" (Davies, 2005, p. 123). On memory in a post-colonial context, Babha pointed out that it is an important yet dangerous bridge between colonialism and the search for a national identity (Babha, 1994). Mantovani constructed this "bridge" when he attempted to resurrect memory through interaction between the characters and the post-colonial space; a parallel to a person who visited a tomb to talk to and expect to receive some power from the dead. To add a supernatural aspect as one prominent Indonesian horror marker, Mantovani turned the cemetery into the spectral monster's dwelling place which complicates the notion of the past as the spectral monster has no concept of time. Thus its existence in the proximity of the colonial building and the terror it inflicts on the dwellers reinforce the contemporaneous nature of the past.

Mantovani reopened past colonial wounds when he utilized the space. As Lowenstein pointed out that "to speak of history's horrors or trauma is to recognize events as wounds" (Lowenstein, 2005, p. 1). There are wounds scattered throughout the film are inflicted on and by the protagonist literally and allegorically within the postcolonial space that cause uneasiness and subconsciously evoke traumatic feelings in the audience. A metaphorical wound is a kind of wound, in Lowenstein's words, that "bleeds through the conventional confines of time and space" (Lowenstein, 2005, p. 1). The film's treatment of time and space is unconventional; the narrative does not seem to progress forward and the characters are trapped within the space in which time apparently does not move. It resonates with Bergson's concept of duration that he formulated as "the continuous progress of the past which gnaws into the future and which swells as it advances" (Bergson, 1944, p. 7). This conflation of time and space further supports the notion of the "ever-present past" that lies as the basis of the analysis.

Mantovani intentionally evoked the aura of a decayed yet living past through cinematography to mystify the building and thus create ambiguous feelings of both forgetting and remembering the past. The intersection between the past and the present within a post-colonial space complicates the identity search but at the same time underlines the significant role of a colonial past in the present search for identity. The building as a post-colonial space becomes a medium where past and present intertwine, time and space conflate.

Multilayered allegorical moments found in the film can be connected as a collision of historical trauma and the search for present identity as well as between traditional and modern values. These moments are constructed based on a dichotomic set which is the colonizers' influencing legacy to present Indonesia.

The first layer is the present oppression as the allegorical moment to the past oppression. Samantha, the protagonist, is an orphan college student who lives with her stepfather. Her stepfather never appears in the film and the audience knows him only through Samantha's narration. His physical absence, though, emphasizes the omnipresent power that surrounds her. The story opens with Samantha leaving home because her stepfather keeps trying to seduce her. This sexual seduction can be read as the oppression by the patriarch that resonates with post- 
colonial reading of the colonizer as the powerful patriarch. Thus, the present oppression by Samantha's stepfather can be read as an allegorical moment to the past when the colonizers attempted to tame and control the "motherland". The oppression does not stop when she leaves home; instead it escalates in different forms in the dorm (the post-colonial space) where she lives now. Sri Sukmarahimi, the dorm owner, represents the colonial past and the old Javanese aristocrat who oppresses Samantha. The interpretation of Sri Sukmarahimi as a representation of the old Javanese aristocrat is significant because it becomes an allegory of power domination during the repressive regime of Soeharto (Indonesia second president). Soeharto's 32-year regime (the New Order) is often associated with an ancient Javanese kingdom, Mataram, which amplifies the aura of aristocracy. There is an ongoing criticism of a "Javanism" government that focuses too much on the development of Java while neglecting the other islands. Pemberton as quoted in Philpott argued that Java "underpins the notion of an ideal Indonesian identity in New Order discourses" (Philpott, 2000, p 43). Although Soeharto has already passed away, the traces and legacies of his power and influence are still apparent today.

Returning to the film, Sri Sukmarahimi attempts to control Samantha when she learns that Samantha shares her talent to control the spectral monster. Sri Sukmarahimi's supernatural inclination provides her longevity which allegorically suggests the colonial power's reluctance to decay. She wants Samantha to join her secret cult society and replace her position. She forces her demand although Samantha refuses, which reflects the colonizers pressuring manner towards the colonized people. It also can be read as reflection of Soeharto's regime, during which violence and forceful actions often accompanied certain policy enforcements.

The allegorical situation is amplified by the choice of Alice Iskak, the actress playing the antagonist. Her mixed racial descent appropriately represents the colonial past, the old Javanese aristocrat, and a certain type of national identity (colonial hybrid): her mother is Dutch and her father is a Javanese aristocrat. As for Samantha, she is depicted as an independent, young, and attractive cosmopolitan woman who perfectly represents capitalistic power (neo-colonialism) and also a certain type of identity (modern hybrid). Thus, the final battle between Samantha and Sri Sukmarahimi signifies the victory of neo-colonialism over the colonial past. Samantha's position in the film is ambiguous; on the one hand, she represents the oppressed (common people), but on the other she embodies capitalist power. This contrasting representation should not be read as inconsistency but as a complex display of identity search in which the past can never be reduced or omitted in the construction of the present identity. It also reflects Babha's liminal space where the oppositions are in dialogue and result in hybridity. Furthermore, the intersection between the power of a colonial past and the present neo-colonialism within the same space in the final battle should not be seen as illogical because it corresponds to the concept of an "ever-present past."

The spectral monster that Samantha is able to control is another layer of oppression. Being a mythical and legendary supernatural being, the spectral monster embodies traditional values that the younger and modern generation no longer remembers. At the same time, the monster also represents the oppressed because it is under the control of the powerful and can only come out if it is called. There is a Hegelian "master-slave" relation between the monster and its human counterpart where the spectral monster cannot identify itself without acknowledging or identifying itself through its relation with its master. This relationship can be read as an allegory of the colonized identity which is constructed by the colonizers. Even after the independence, this "master-slave" mentality is still dominant and complicates the national identity search.

In another layer, the fact that, in the end Samantha carries within herself the ability to summon the monster reflects an identity form that the director asserted to the audience: a hybrid that combines modern and traditional values, a phenomenon which Pramod K. Nayar argued in Postcolonialism: A Guide for the Perplexed is the result of the post-colonial diaspora. Women as protagonists as well as victims are an identifiable marker of the Indonesian horror genre and function as a parallel to the Other in the post-colonial discourse. This also reflects the dichotomy between colonizers as the patriarch and the effeminized colonized. Similar to many Southeast Asian horror genres, the hidden pasts by which this film is haunted are particularly those pertaining to women's oppression. Knee stated that "the past and the feminine are figured as sources of anxiety through their linkage to the supernatural, an anxiety that these texts choose variously to exorcize or come to terms with" (Knee, 2005, p. 142). Knee's argument provides a possible explanation for the director's choice of women's protagonist and antagonist.

\section{Conclusion}

Mantovani's assertion of hybrid identity has already become the portrait of a majority of urban Indonesians today. Most of them live under two contrasting values - the modern and the traditional — which greatly influences their lives. The Indonesian horror genre itself is, to some extent, a hybrid; it engages modern global, Hollywood-like 
conventions of the horror genre, but also refers back very specifically to a local genre tradition, itself deeply rooted in local myth, legend, or folklore. The intertwined modern and local values within the genre suggest ambiguity in the director: on one hand he seems to be conscious of the powerful force of modernism/capitalism that erodes the traditional values. He intentionally performed decolonization attempts by reviving mysticism and spiritualism in his film. On the other hand, he is also conscious of capitalist marketing power and employs its strategies to draw an audience and make a profit, for example by casting famous people of mixed racial descents, launching huge promotion campaign, and enjoying big production budget. From the elaboration above, one can see how film becomes an efficient tool to deliver one's message. As Hopkins argued that "the cinematic landscape is...ideologically charged cultural creation whereby meanings of place and society are made, legitimized, contested, and obscured" (Hopkins, 1994, p. 47).

Simplistic as it seems, the concept of hybridity is far from simple. Sanjines argued that the concept of hybridity "separates and deterritorializes the binary opposition" (Sanjines, 2007, p. 306) which also reflects Bhabha's liminal space. In this light, Mantovani thus has attempted to break away from a dichotomic mindset through his modern hybrid identity. However, Sanjines stated that there are consequences with hybridity; it ends up surrendering the identity to the market and globalization. Dirlik argued that "hybridization of identities is an ongoing historical process" (Dirlik, 2011, p. 428). From this point of view, Mantovani's search for national identity is not a closed process as identity is fluid and ever-changing. He merely offers one form of identity at a certain period of time for certain group of people in Indonesia, i.e. the teenagers/youngsters. The analysis also suggests that hybridization of identities has become the marker of contemporary post-colonial societies in which the colonial past still plays an important role in the post-colonial/post-modernism present.

\section{References}

Aitken, S. C. \& Leo E. Z. (Eds.), 1994, Place, Power, Situation, and Spectacle (Maryland: Rowman \& Littlefield Publishers, Inc.).

Babha, H. K., 1994, The Location of Culture (New York: Routledge).

Bergson, H., 1944, Creative Evolution (New York: Random House, Inc.)

Davies, D. J., 2005, A Brief History of Death (Malden: Blackwell Publishing).

Deleuze, G., 1998, Bergsonism (New York: Zone Books).

Dirlik, A., 2011, Rethinking Colonialism: Globalization, Postcolonialism, and the Nation. International Journal of Postcolonial Studies, 4(3), 428-488.

Dizayi, S.A.H., 2015. The Crisis of Identity in Postcolonial Novel. Proceedings of 2nd International Conference on Education and Social Science, Istanbul, Turkey, February, pp. 999-1007

Faulkner, W. 1951, Requiem for a Nun (New York: Random House).

Forshee, J., 2006, Culture and Customs of Indonesia (Westport:Greenwood Press).

Gandhi, L., 1998, Postcolonial Theory: A Critical Introduction New York: Columbia University Press).

Hopkins, J., 1994, A Mapping of Cinematic Places: Icons, Ideology, and the (Mis) representation. In: Place, Power, Situation, and Spectacle, edited by Stuart C. Aitken \& Leo E. Zonn (Maryland: Rowman \& Littlefield Publishers, Inc.), pp. 47-68.

Keith, M. \& Steve P. (Eds.), 1993, Place and the Politics of Identity (London: Routledge).

Khair, T., 2009, The Gothic, Postcolonialism and Otherness: Ghosts from Elsewhere (New York: Palgrave McMillan).

Knee, A., 2005, Thailand Haunted: The Power of the Past in the Contemporary Thai Horror Film. In: Horror International, edited by Steven Jay Schneider \& Tony Williams (Detroit: Wayne State University Press), pp. 141159.

Mantovani, R., 2006, Kuntilanak (Indonesia: MVP Pictures).

Kusno, A. 2010, The Appearances of Memory: Mnemonic Practices of Architecture and Urban Form in Indonesia (Durham: Duke University Press).

Lim, B. C., 2009, Translating Time: Cinema, the Fantastic, and Temporal Critique (Durham: Duke University Press). 
Lowenstein, A., 2005, Shocking Representation: Historical Trauma, National Cinema, and the Modern Horror Film (New York: Columbia University Press).

Nas, J. M., (Ed.), 2006, The Past in the Present: Architecture in Indonesia (Rotterdam: NAI Publishers).

Philpott, S., 2000, Rethinking Indonesia: Postcolonial Theory, Authoritarianism and Identity (Houndmills: MacMillan Press Ltd.).

Sanjines, J., 2007, The Nation: An Imagined Community? Cultural Studies, 21(2-3), 295-308.

Stenner, P., 2018, The Risky Truth of Fabulation:Deleuze, Bergson and Durkheim on the Becomings of Religion and Art. Annual Review of Critical Psychology, 14, 149-172. 